\title{
أقوال الصحابة التي لايعرف لهم فيها مخالف من المحلى لابن حزم \\ الاليات نموذجًا (جمعا ودراسة)
}

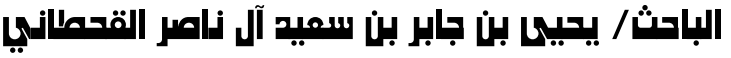

حاصل على درجة الماجستير في الفقه المقارن

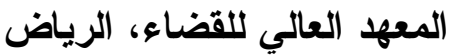

المملكة العربية السعودية

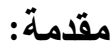

إنّ الحمد لله، نحمده و نستعينه، ونستغفره، ونعوذ باله من شرور أنفسنا ومــن سـيئات

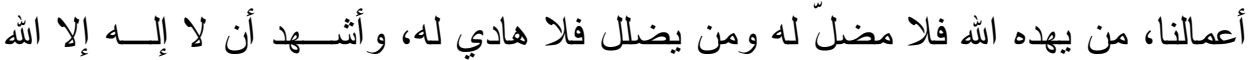

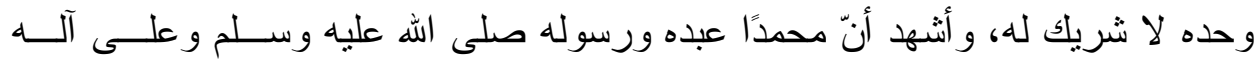

وصحبه أجمعين. أما بعد:

فإنّ الله عز وجل قد بعث نبيه صلى الله عليه وسلم إلى أمته ليرشدهم ويعلمهــم أمــر

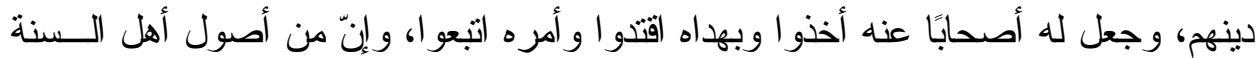

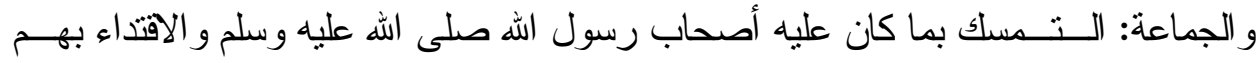

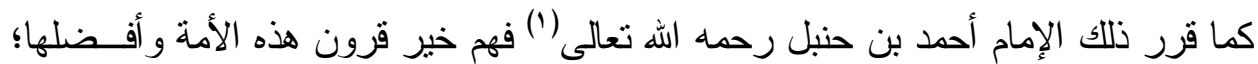

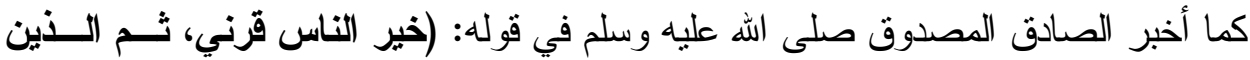

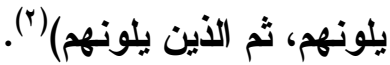

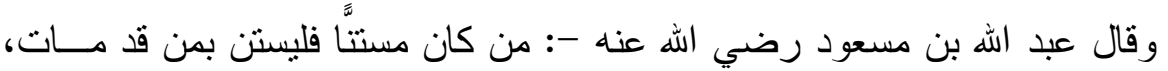

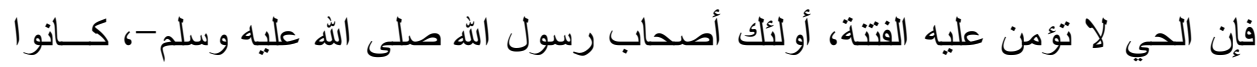

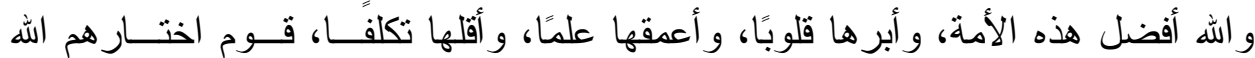


لصحبة نبيه و إقامة دينه، فاعرفو الهم فضلهم و اتبعوهم فـي آثـار هم، وتمـسكو ا بمـــا

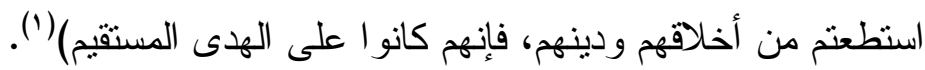

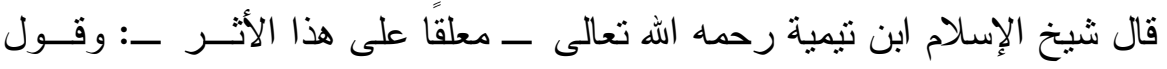

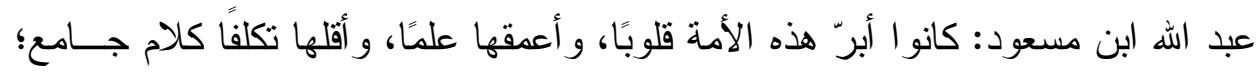

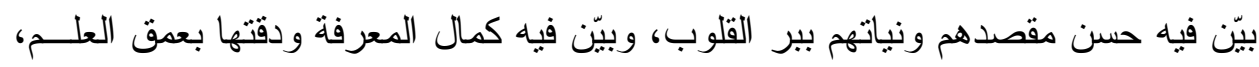

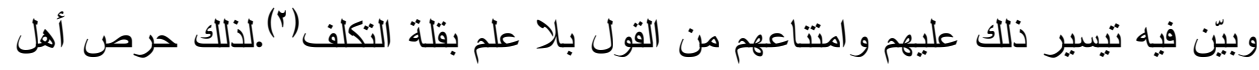

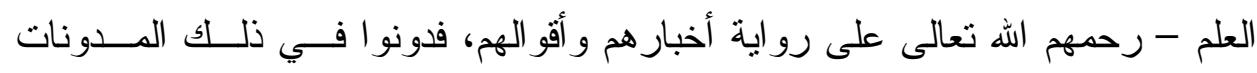
وصنّفو المصنفات التي حوت كل ما نقل عنهم بصحيح الأسانيد وضعيفها، وقد صارت

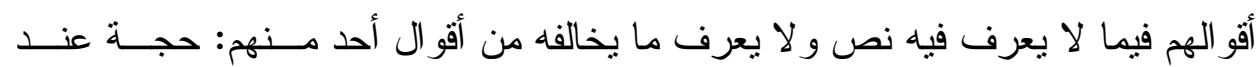

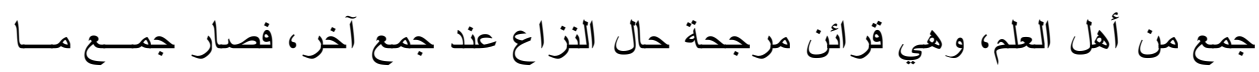

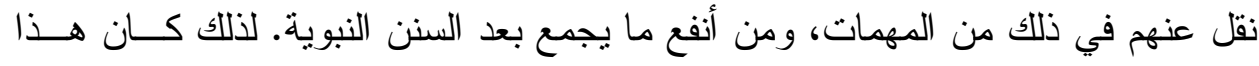

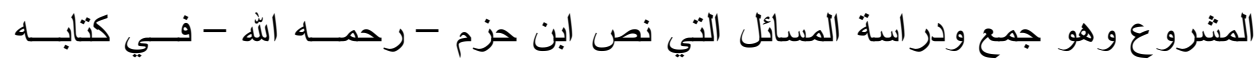

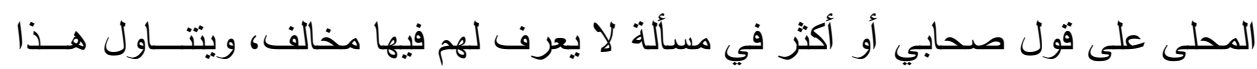

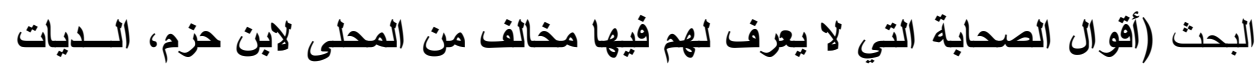

نموجًا، جمعًا ودر (سدة).

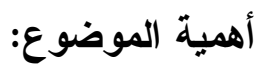

نظهر أهمية موضوع البحث في عدة نقاط:

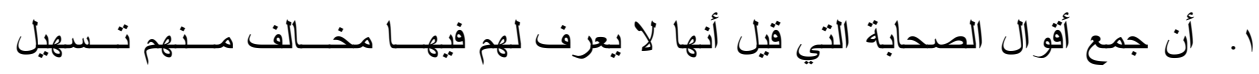

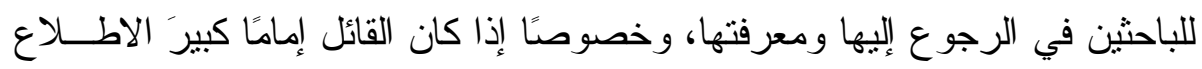

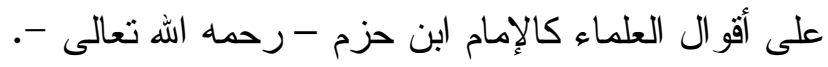

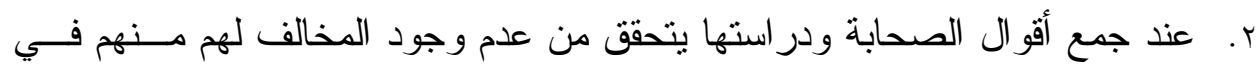
المنقول، فيطمئن القلب عند الحديث في مسائل الاتفاق والخلاف عند الفقهاء ونقلها.

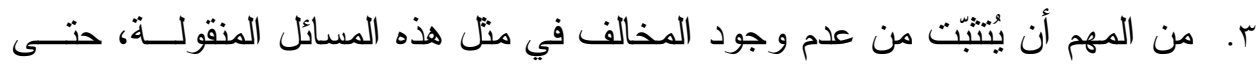
يكون الاستدلال و الاعتر اض صحيحًا عند مناقنة أقو ال أهل العلم. 


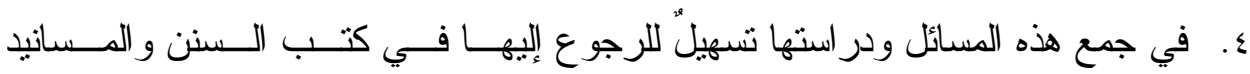
و المصنفات.

ه. بتخريج الآثار الواردة عن الصحابة و التأكد من صحتها أو ضعفها، يُتبـــت صــــة عزو هذه المسائل إلى أصحابها أو عدمه.

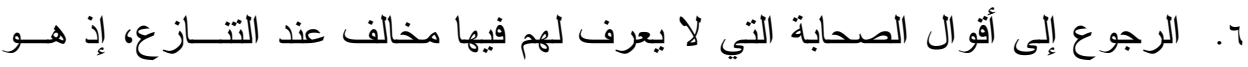
حجة شرعية عند جمع من أهل العلم. V. معرفة المخالف من أهل العلم لهذه المسائل، ومعرفة المو افق لها، وهذا من الأمــور المعينة على الترجيح بين الأقو ال. أسباب اختيار الموضوع: ا. التقرب إلى الله عز وجل بالسعي في جمع أقو ال الصحابة رضي الله عنهم - الذين هم أعلم الناس بالثر ع بعد نبينا صلى الله عليه وسلم. r. أهمية الموضو ع التي سبق بيانها.

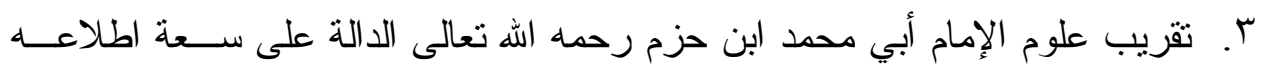

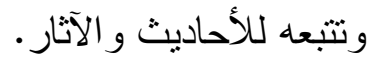
ع. أنيّ لم أجد من نتبع أقو ال الصحابة التي لا يعرف لهم فيها مخالف وجمعهــا فـي

$$
\text { منهج البحث: موضع واحد. }
$$

1. تصوير المسألة تصويرًا دقيقًا قبل بيان حكمها؛ ليتضحَ المقصودُ من در استها.

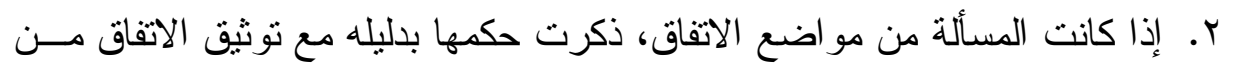
مظانه المعتبرة. r. إذا كانت المسألة من مسائل الخلاف، اتبعت ما يلي:

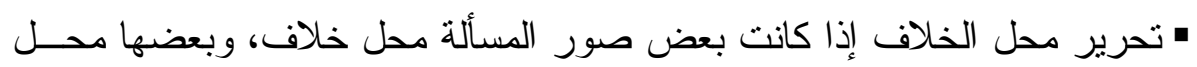
اتفاق.

• ذكر الأقو ال في المسألة وبيان مَن قال بها من أهل العلم، ويكون عرض الخلاف حسب الاتجاهات الفقهية. 
• الاقتصار على المذاهب المعتبرة، مع العناية بذكر ما تيسر الوقوف عليـهـ مـن

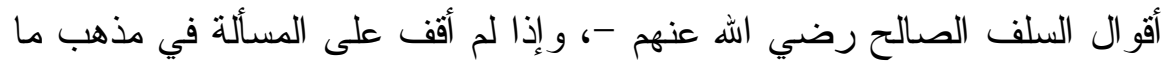
سلكت بها مسلك التخريج. • توثيق الأقو ال من مصادر ها الأصبيلة.

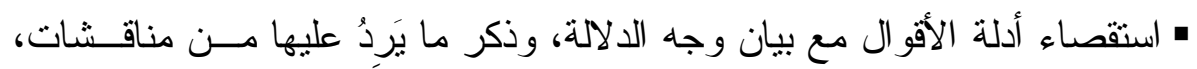
وما يجاب به عنها إن أمكن ذللك، و ذكر ذلك بعد الاليل مباشرة.

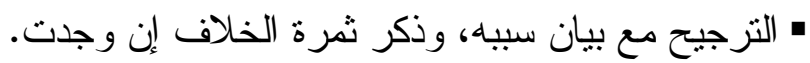

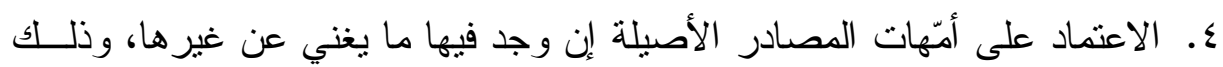
في التحرير و التوثيق و التخريج و الجمع. 0. التزكيز على موضوع البحث، وتجنب الاستطر اد.

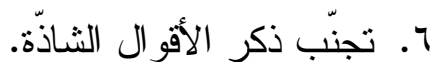

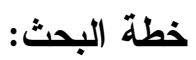

يشتمل هذا البحث على مقدمة، وسبعة مباحث، بيانهم فيما يلي:

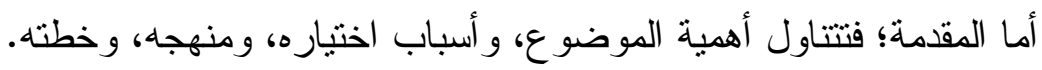

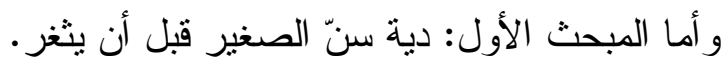

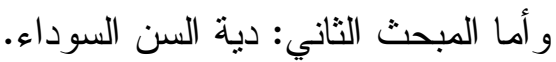
وأما المبحث الثالث: دية عين الأعور. و أما المبحث الر ابع: دية العين. وأما المبحث الخامس: دية شفر العين. و وأما المبحث السادس: دية الحاجب.

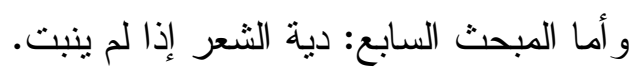

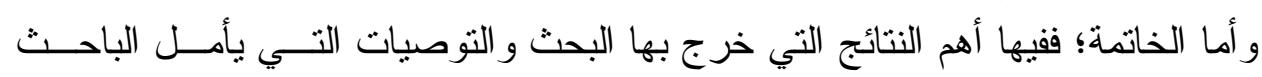




\section{المبحث الأول \\ دية سن الصغير قبل أن يثغر}

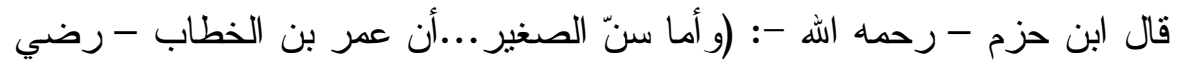

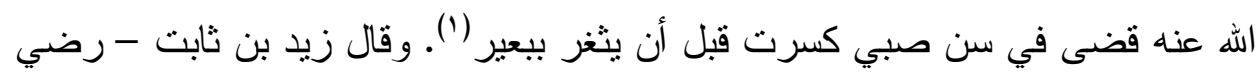

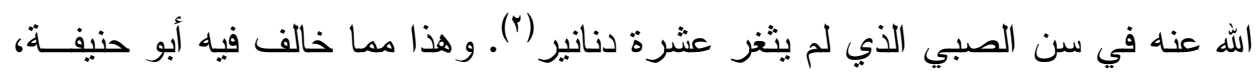

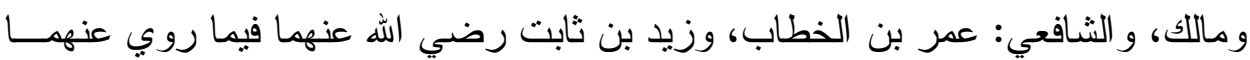
في هذا الباب، و لا يعرف لهما مخالف من الصحابة رضي الله عنهم) (َّاب.

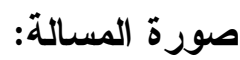

إذا قلعت سن الصبي أو كسرت قبل أن يثغر (أي تسقط أسنانه) فماذا يجب فيها ؟

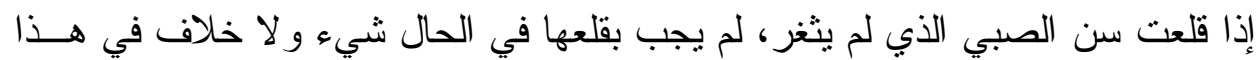

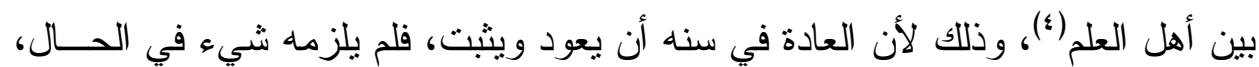
كما لو نتف شعره(0). ولكن ينتظر عودها، فان مضت مدة بيأس من عودها، وجبت ديتها.

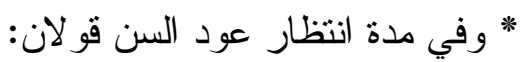

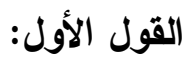

أنه يتوقف سنة، وذهب إلى هذا الحنفية(")، و المالكية(V)، و الحنابلة (^). دليلهم: لأن ذلك هو الغالب في نباتها.

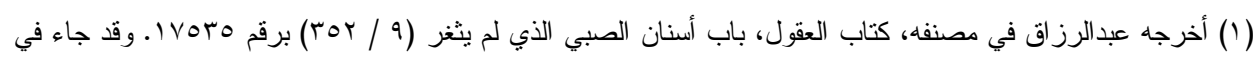

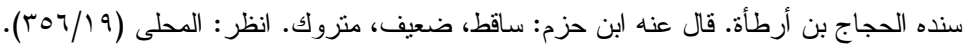

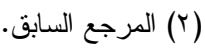

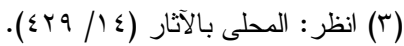

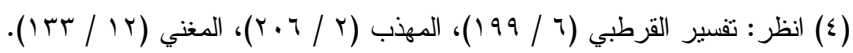

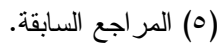

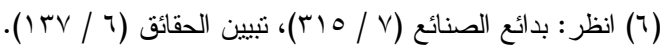

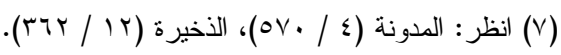

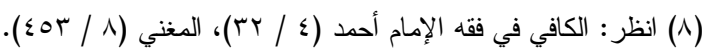


أنه إذا سقطت أخو اتها ولم تعد هي أخذت الدية. ذهب إليه القاضي(') مـــن الحنابلـــة(؟)، ولم يذكر مقدار مدة سقوط أخو اتها.

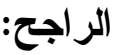

الذي يظهر للباحث في ذلك إرجاع تحديد المدة الى أهل الخبرة، وهم الأطباء.

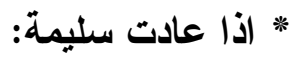

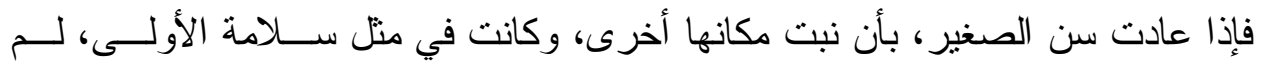

$$
\text { تجب فيها الدية. وهل يجب فيها شيء آخر ؟ القول }
$$

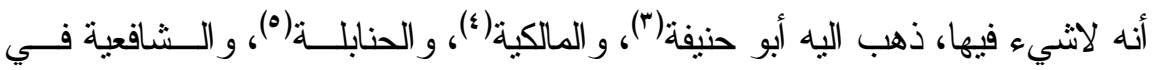

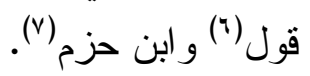

دليلهم: قالو ا كما لو أنه نتف شعره فر فعاد (^).

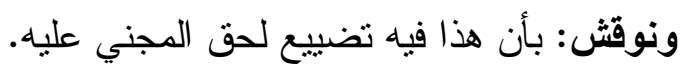

القول الثاني:

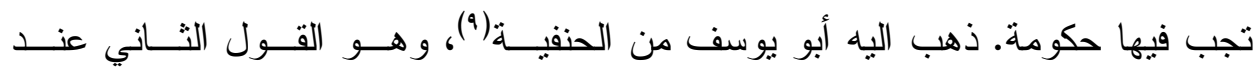

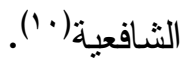

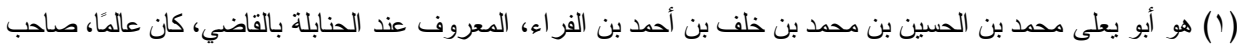

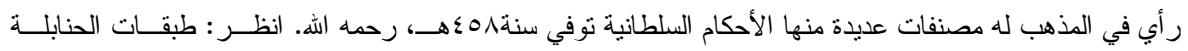

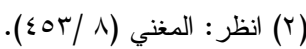

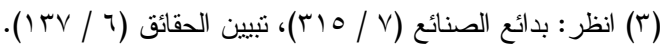

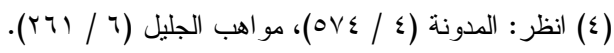

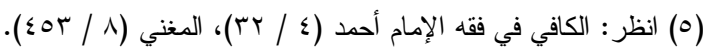

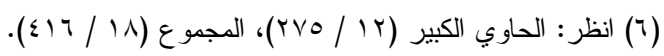

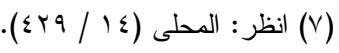

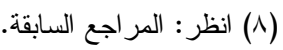

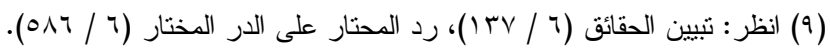

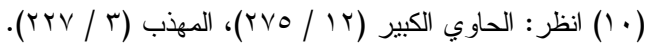


دليلهم: قالو ا بوجوب الحكومة وذلك للألم و الجرح الذي حصل بالقلع.

الترجيح:

الذي يظهر للباحث أن القول الثاني هو الراجح لأن الأول فيـــهـ مخالفـــة للأدلــــة الو اردة في القود، أو في الدية في كل جناية. * أما إذا عادت مشوهة:

فتجب فيها الحكومة، نص على ذلك الحنابلة(1)، وهو قياس قول بقية المــذاهب، لأن الظاهر أن ذلك بسبب الجناية عليها(؟). * أما إذا لم تعد السن كاتت كسن الرجل ووجب فيها خمس من الإبل.

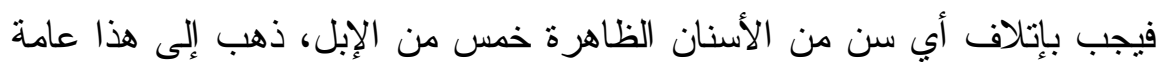

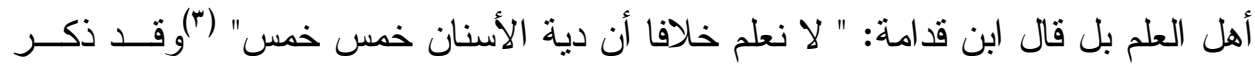

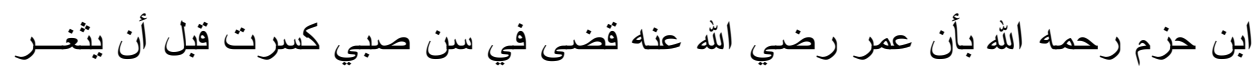

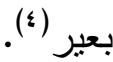
وقال زيد بن ثابت رضي الله عنه: " في سن الصغير الــذي لــــيثغــر عـشرة دنانير "(•)

قال ابن حزم رحمه الله: وهي قيمة البعير عندهم في الدية(؟)، أبي: العشرة الدنانير • الر اجح: الذي يترجح لدى الباحث أن فيها خمس من الإبل لما جاء عن عمر بـن شـعيب

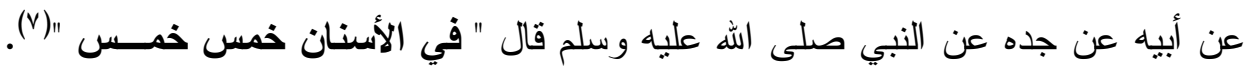
و هذا نص في المسألة. و الله أعلم.

$$
\begin{aligned}
& \text { (1) انظر : الثرح الكبير (Y / / • (YV). }
\end{aligned}
$$

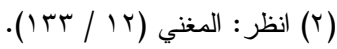

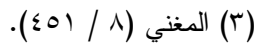

$$
\begin{aligned}
& \text { (ع) سبق تخريجه صو (1) } \\
& \text { (0) سبق تخريجه ص } 99 .
\end{aligned}
$$

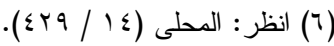

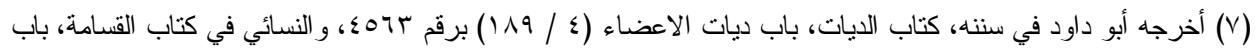

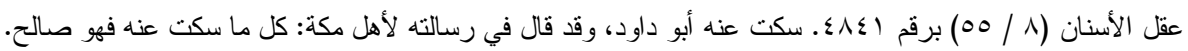


المبحث الثاني: دية السن السوداء:

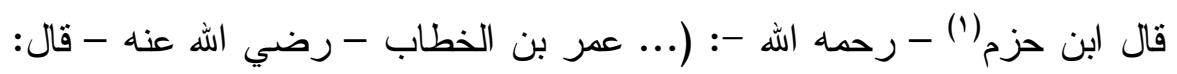

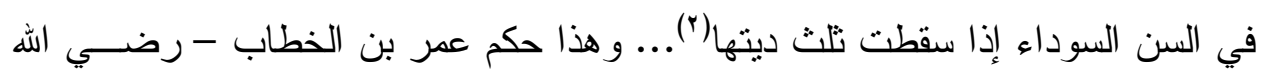

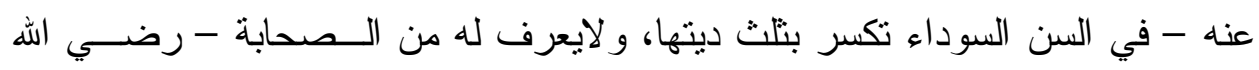
عنهم - مخالف). صورة المسألة:

إذا قلعت السن السوداء الكاملة المنفعة خطأ، فما الو اجب فيها ؟ اختلف الفقهاء في ذلك على خمسة أقو ال:

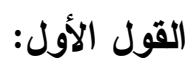
أن الو اجب فيها ثلث ديتها. ذهب اليه أحمد في رواية عنه(").

أدلتهم: ا - ما روى عمرو بن شعيب عن أبيه عن جده أن رسول الله صلى الله عليه وســلم " قضى في العين العوراء السادة لمكانها إذا طمست بثلث دئ ديتها، وفي اليد الثنلاء

إذا قطعت بثلث ديتها، وفي السن السوداء إذا نزعت بثلث ديتها " (؛).

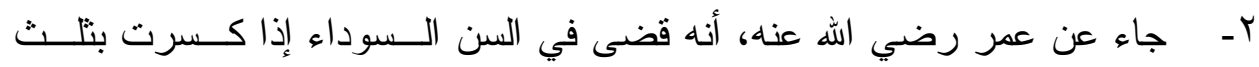

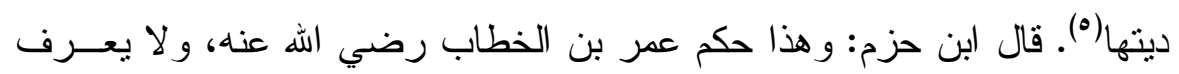
له مخالف من الصحابة رضي الله عنهم (`).

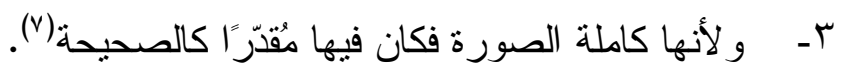

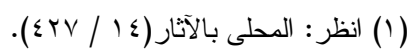

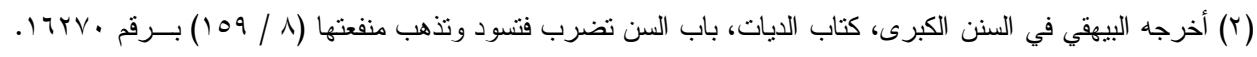

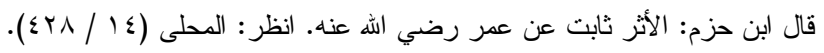

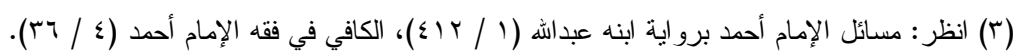

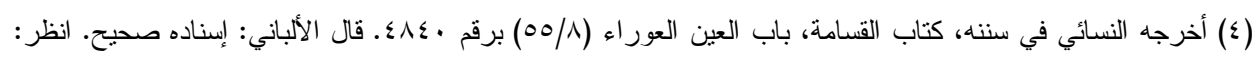

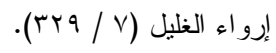

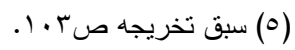

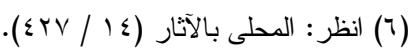

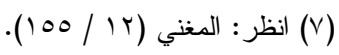




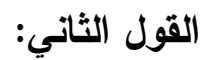

إذا نبتت سوداء في الأصل وكانت كاملة المنفعة وقلعت ففيها ديتها، و إن كانـــ

في الأصل بيضاء فلما ثغر نبتت سوداء فهنا يُسأل أهل الخبرة: فإن فالو ال ال يكون السو اد إلا لعلة حادثة فقي قلعها حكومة.

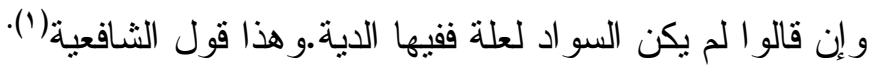

القول الثالث:

تجب فيها الدية كاملة وهي خمس من الإبل. ذهب إليه المالكية(؟)، و اختاره القاضي من

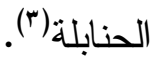

أدلتهم:

1 - بقاء منفعتها لأن منفعتها سوداء وبيضاء و احدة فلم تتقص فيها الدية(ع).

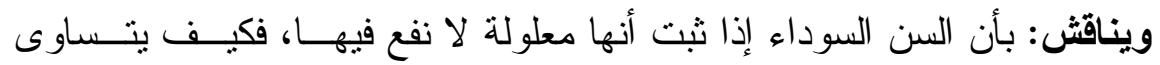
أرشها بأرش السن السليمة.

r- القياس على الأنف الذى ذهب شمه إذا قطع، فيه الدية كاملة لذهاب جمالد(ه).

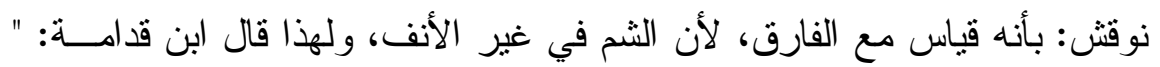

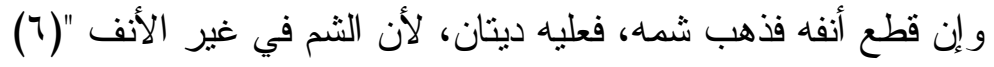

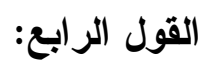

أن فيها حكومة. ذهب إليه الحنفية(V)، و أحمد في رو اية (^). دليلهم: قياسًا على العين القائمة'(9).

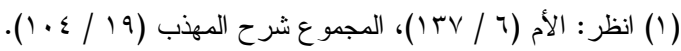

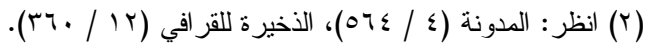

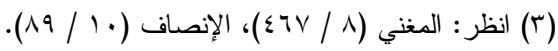

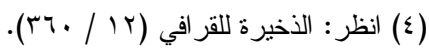

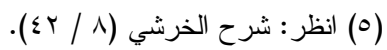

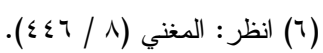

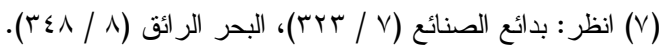

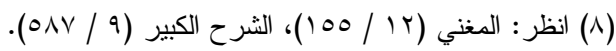

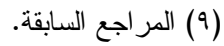




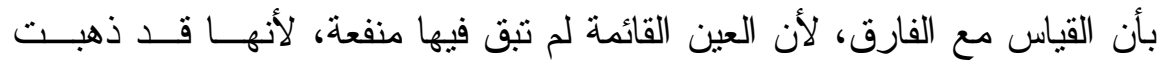
منفعتها و لا مقدر فيها.

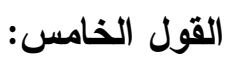

ليس في ذلك شيء، وذهب إلى هذا ابن حزم ('). دليله:

لأنّ الخطأ مرفوع بنص القرآن، فلا يجوز البتة إيجاب غرامة في ذلـــك، لأنـــــ

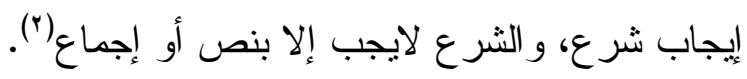
الر اجح: - (الرع الذى يظهر للباحث رجحانه هو ما ذهب إليه أصحاب القول الأول، وهو أن في الــسن السوداء الكاملة المنفعة إذا قلعت خطأ تلث ديتها.

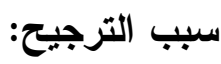

1- ل للحديث المذكور في القول الأول. r- - و لأنه قضاء عمر رضي الله عنه ولم يعرف له مخالف من الصحابة، كمـــا قــال ابن حزم رحمه الله. المبحث الثالث: دية عين الأعور:

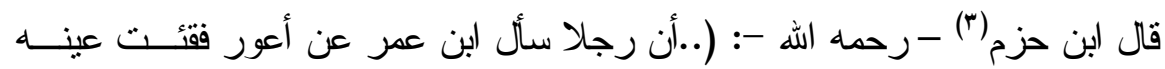

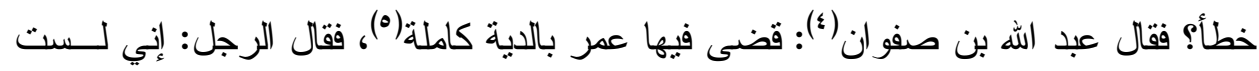
إياك أسأل، إنما أسأل ابن عمر؟ فقال: ابن عمر رضي اله عنه يحدتك عن عمر وتـسألني.

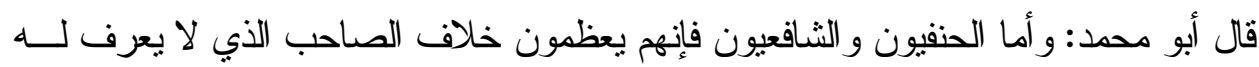

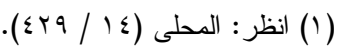

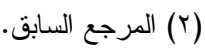

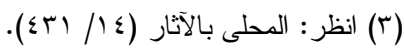

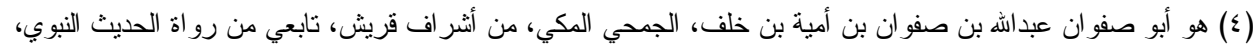

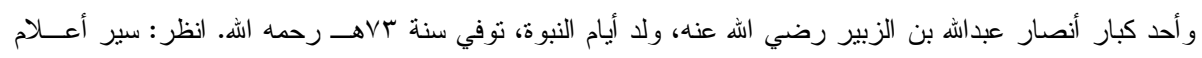

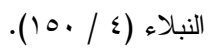

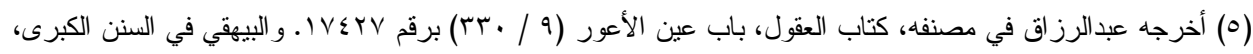

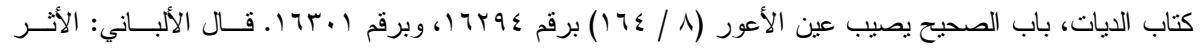

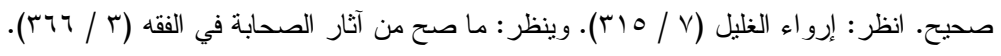


مخالف، و هم قد خالفوا هاهنا: عمر، و ابن عمر، وعليًا، وابن عباس رضــي الله عـنهم لا يعرف لهم في هذا من الصحابة رضي الله عنهم مخالف). صورة المسألة:

لو فقأ شخصٌ عين أعور خطأ، فماذا يجب فيها؟ اختلف الفقهاء في ذلك على ثلاثة أقو ال:

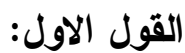

أن فيها الدية كاملة. ذهب إليه المالكية(') و الحنابلة (ץ) رحمهم الله. أدلتهم: - (- n

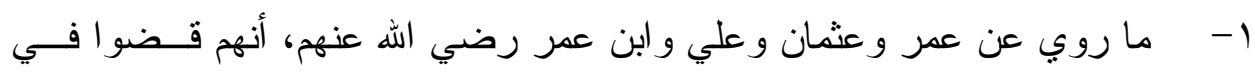

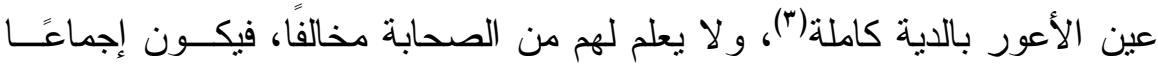

r- أن قلع عين الأعور بيضـمن إذهاب البصر كله كما لو أذهبه من العينـين، لأنـــهـ يحصل بعين الأعور ما يحصل بالعينين (ه).

القول الثاني: - 20

أن فيها نصف الدية. ذهب إليه الحنفية(؟) والــشافعية(V)، وهـــو قــول النخعـي؛

و الثوري (^) رحمهم الله جميعا.

أدلتهم:

ا - قوله صلى الله عليه وسلم: (وفى العين الواحدة خمسون من الإبل)(9).

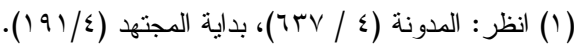

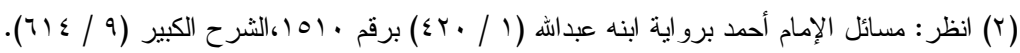

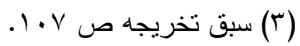

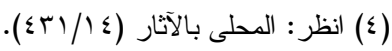

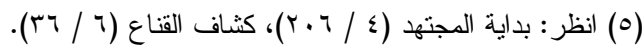

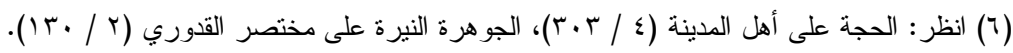

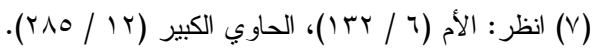

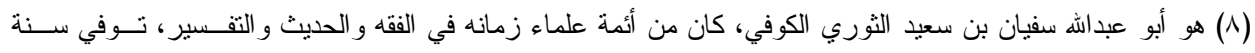

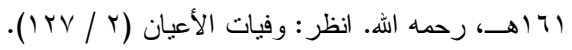

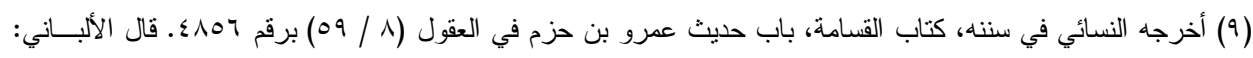

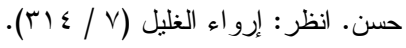




\section{r- قوله صلى الله عليه وسلم: (وفى العينين الاية)(').}

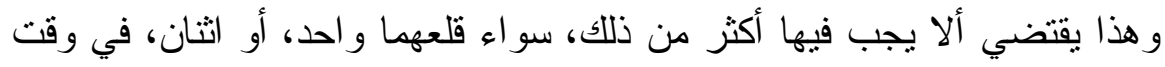

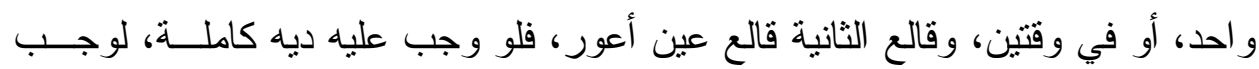

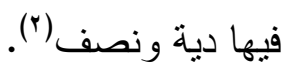

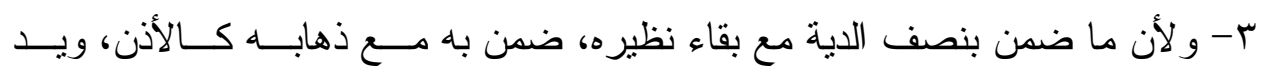
الأقطع (َ).

ونوقش: بالفارق، لأن العين الواحدة تقوم مقام العينين، بخلاف ما ذكروه.

القول الثالث: - 2 الثن

$$
\text { ليس في ذلك شيء، وذهب إلى هذا ابن حزم(ع). }
$$

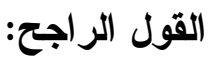

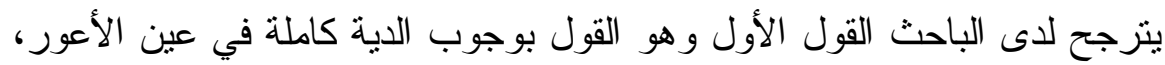

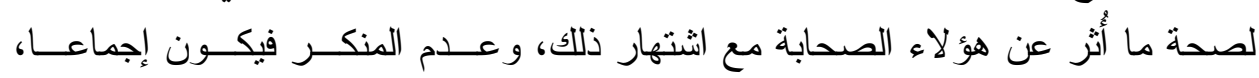
ولضعف أدلة الأقو ال الأخرى ومناقشتها. و الله أعلم.

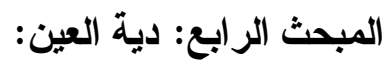

قال ابن حزم - رحمه الله -: (...عن عمر بن الخطاب - رضي الله عنه قـال:

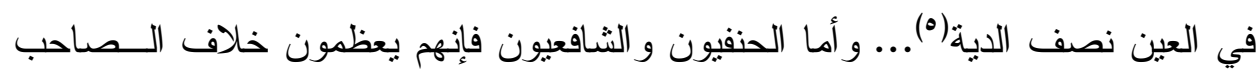

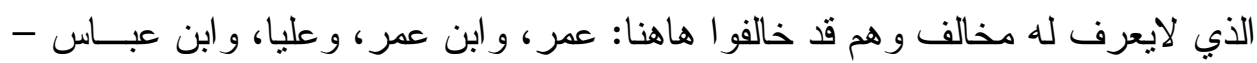
رضي الله عنهم - لايعرف لهم في هذا من الصحابة - رضي الله عنهم - مخالف) (“).

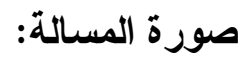
إذا أتلف شخصٌ عينًا سليمة لآخر خطأ، فما الو اجب في ذلك ؟ ورج

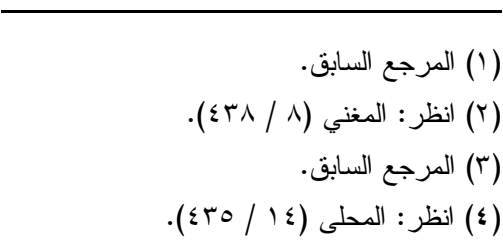

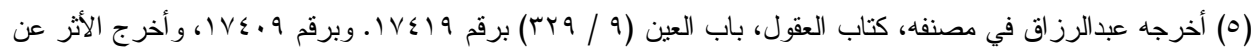

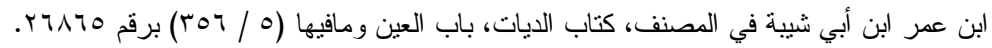




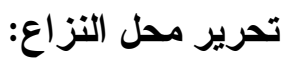

أولًا: أجمع أهل العلم رحمه الله على أن في العينين إذا أصييتا خطأ الدية، وفـي

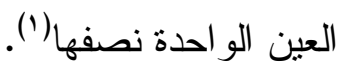

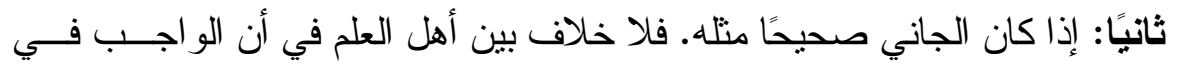

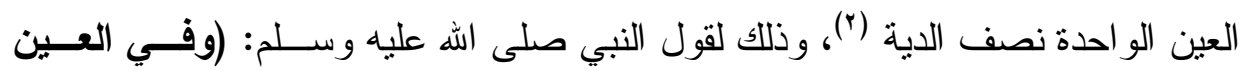

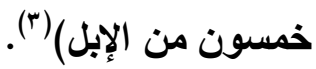
ثالثًا: إذا كانت الجناية خطأ وكان الجاني أعور ، فلا خلاف أيضًا بين أهل العلم في

أن الذي يجب بهذه الجناية نصف الاية( §).

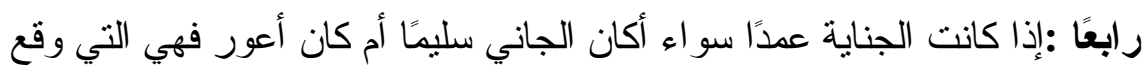

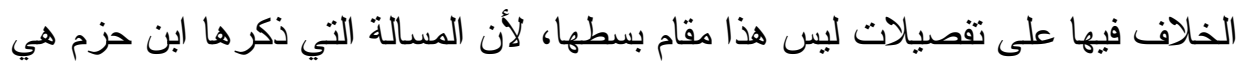

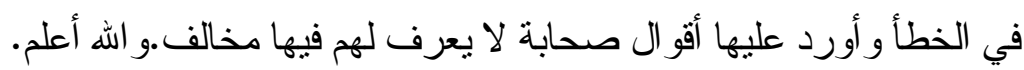
المبحث الخامس: دية شُفْر العين:

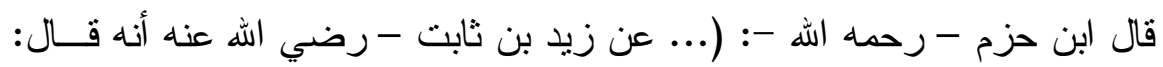

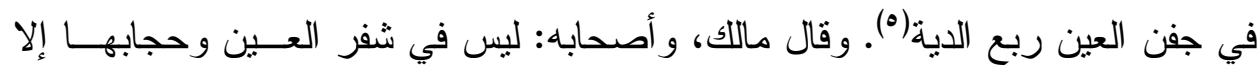

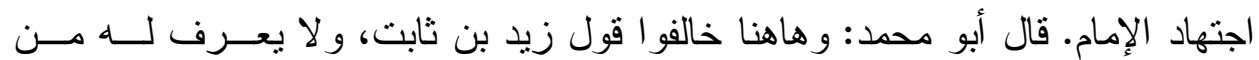

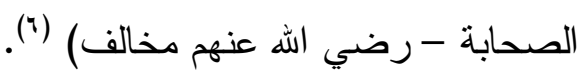
صورة المسألة:

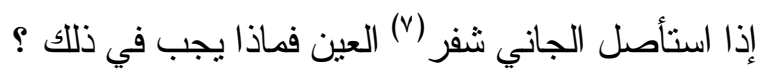
اختلف الفقهاء في ذلك على ثلاثة أقو ال:

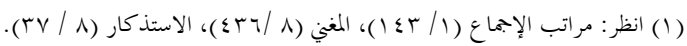

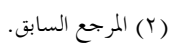

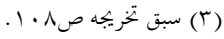

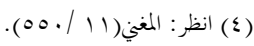

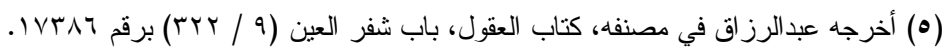

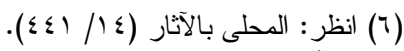

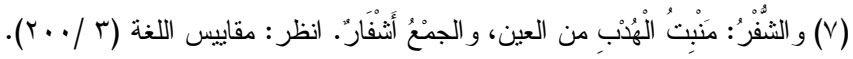




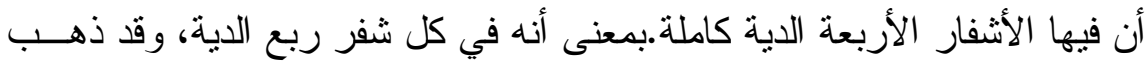

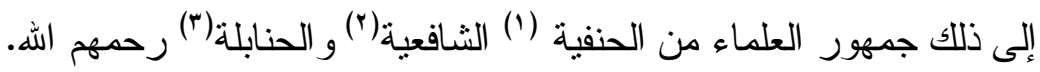
أدلتهم: (1)

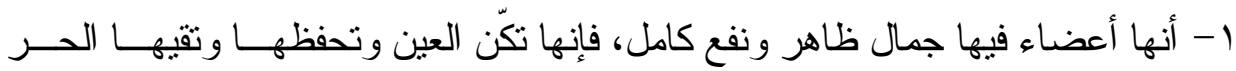
و البرد، ولو لاها لقبح منظر العين.

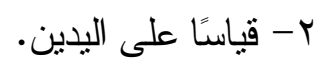

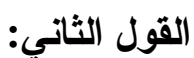

أن فيها الاجتهاد من الإمام. ذهب لذلك المالكية (؛).

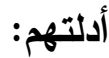

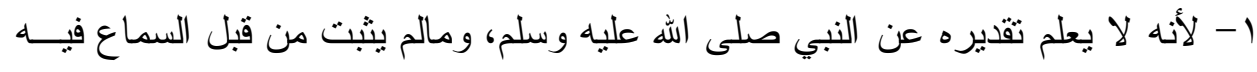

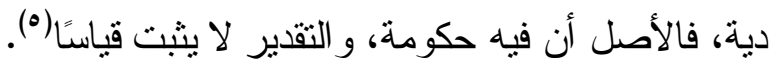
ونوقش بعدم التسليم بأن التقدير لا يثبت قياسًا.

ץ- و لأن إذهابه إذهاب للجمال فلم يجب فيه الدية كشعر الر أس و اللحية( آ). ونوقش: بعدم التسليم بأن الذي فيه الجمال فقط. إذ هي تقي العين من كل ما يؤذيها.

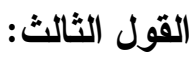
لا يجب في ذلك شيء. ذهب إلى هذا ابن حزم) أدلتهم:

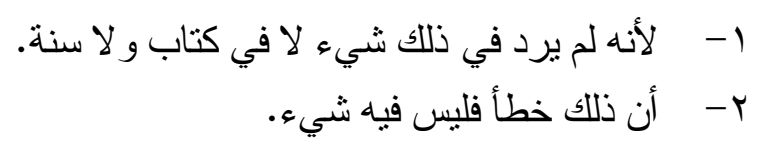

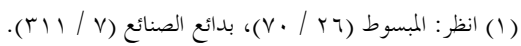

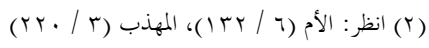

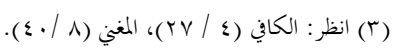

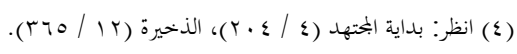

(1) (1) المر اجع السابقة. (7) (7) المراجع السابقة.

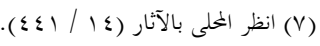




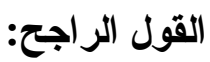

يترجح لدى الباحث القول الأول .لقوة أدلة أصحابه. وعلى ذلك ففي كل جفن ربع

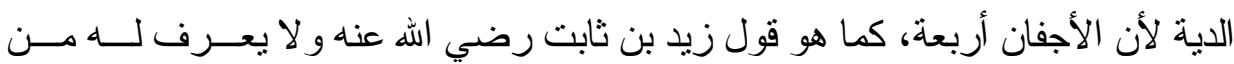
الصحابة مخالف، قاله ابن حزم رحمه الله. و الله أعلم. الهان.

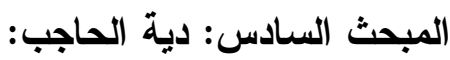

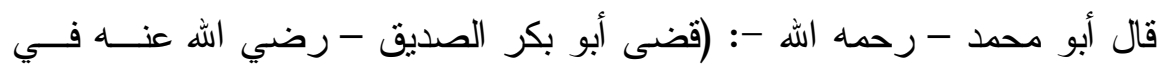

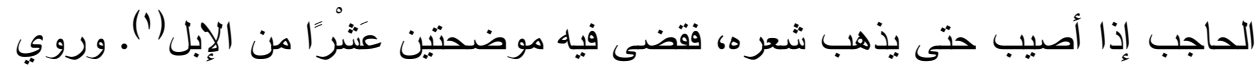

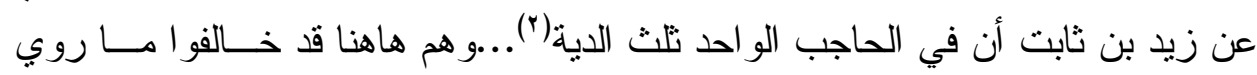

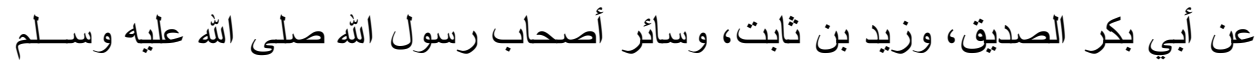

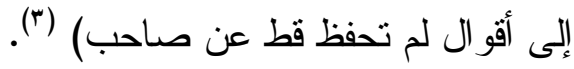
صورة المسالة: - مئ

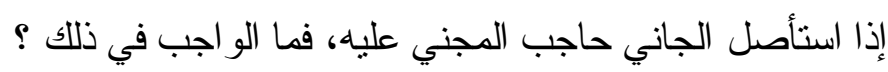

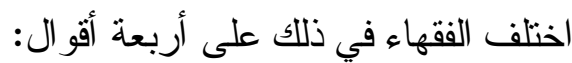

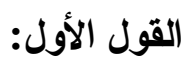

تجب الدية كاملة في إبانة الجفون. ذهب إلى هذا الثافعية (؛) الحنابلة (•).

أدلتهم: (1) - (1)

1 - لأنها أعضاء فيها جمال ظاهر ونفع كامل، فهي تحفظ العين من كل ما يؤذيها.

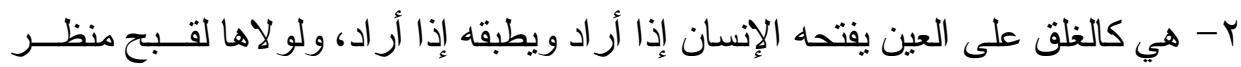

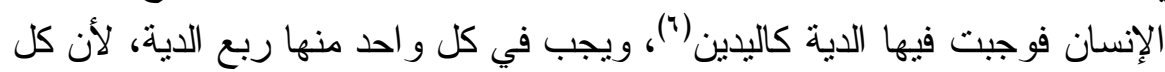

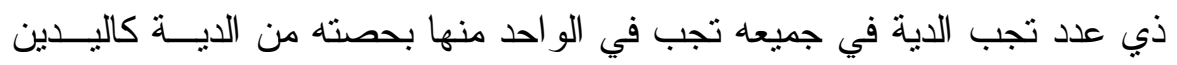

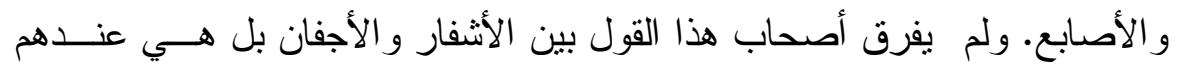
بمعنى و احد.

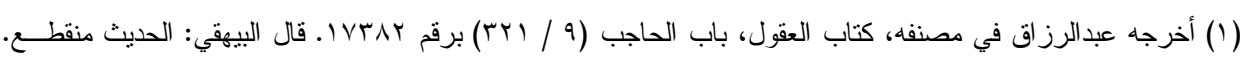

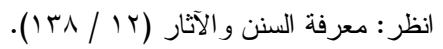

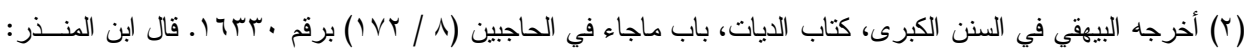
و لايثبت هذا الأثر عن زيد.

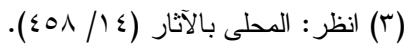

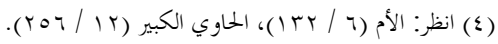

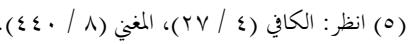

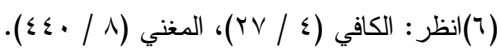


فرَّو ا بين الأشفار و الأجفان، فالأشفار هي منابت الأهداب و الجفــون تابعـــة لهــــا

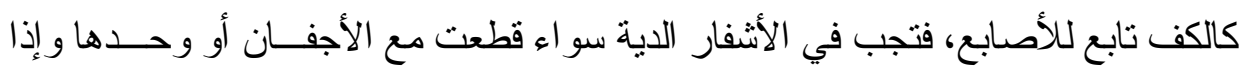
قطعت الأجفان (الحاجب) وليس لها أثنفار فقيها حكومة.

وذهب الى هذا الحنفية(1).

ونوقش:

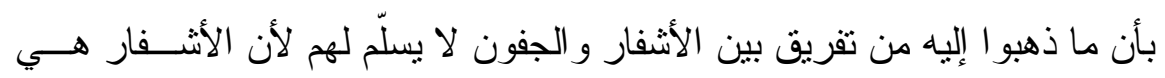

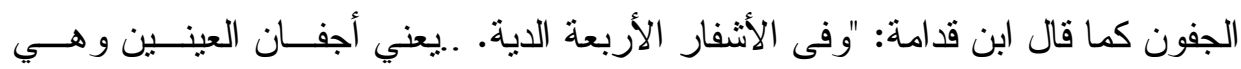

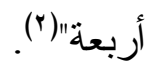
القول الثالث:

تجب في إبانة الجفون حكومة. ذهب إلى ذلك المالكية(ّ).

لأنه لم يعلم فيها دية مقدرة عن النبي صلى الله عليه وسلم، و التقدير لا يثبت قياسًا.

ونوقش:

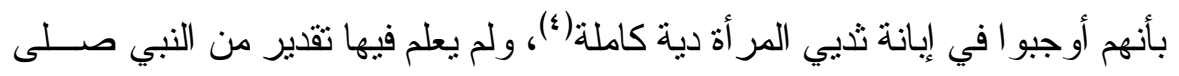

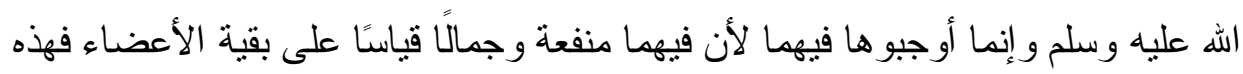
الجفون أيضًا فيها منفعة وجمال.

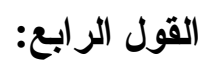
إن كان الفعل عمدًا فليس فيه إلا القود أو المفاداة، و إن كان خطأ فليس فيه شــيء.

$$
\text { ذهب الى هذا ابن حزم (•). }
$$

أدلتهم: (1)

1 - لأنه ليس هنالك نص في الحاجبين يصح و لا إجماع. r- - و لأن الأمو ال محرمة، و الحكومة غر امة فلا يجوز إلز امها أحد بغير نص أو إجماع.

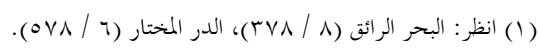

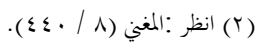

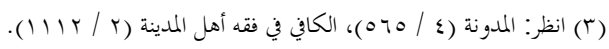

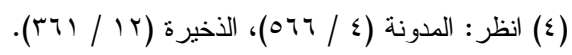

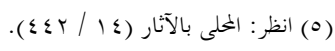


الذي يترجح لدى الباحث هو القول الأول، لقوة أدلته. المبحث السابع: دية الشعر إذا لم ينبت: لإيث:

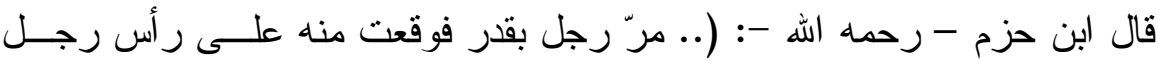

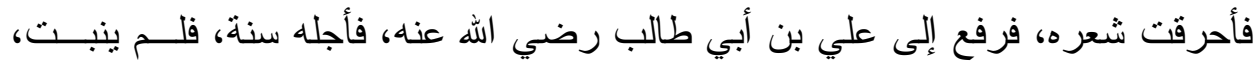

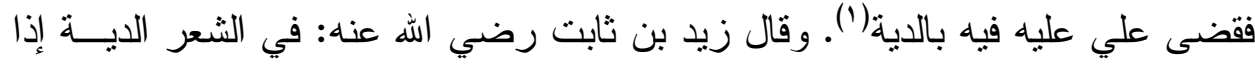

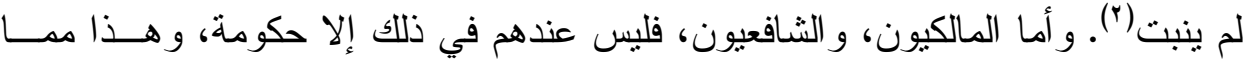

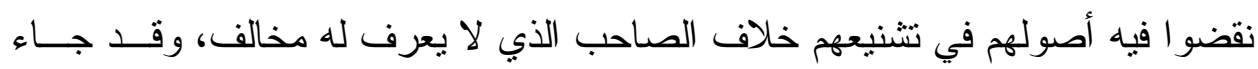

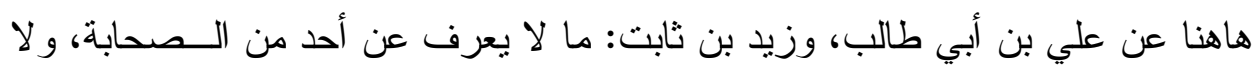

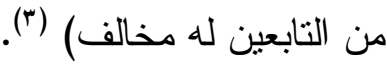

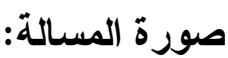
إذا جنى شخصٌ على آخر فأحرق شعر رأسه فلم ينبت بعد ذلك فما الو اجب علــى الجاني اختلف الفقهاء في ذللك على قولين:

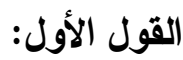
أن فيه الدية. ذهب الإول: إليه الحنفية(؛) و الحنابلة(•).

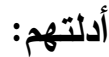

1 - ما روي عن علي وزيد رضي الله عنهما أنهما قالا في الشعر : فيه الدية(؟). ونوقش: بأنه ليس بثابت عنهما ثم أي شعر أر أد ادا. r- لأنه أذهب الجمال عن الكمال فوجبت لبابت فيه الدية كأذن الأصم.

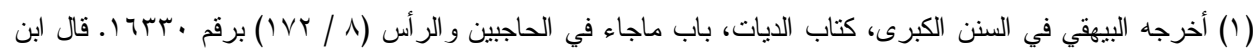

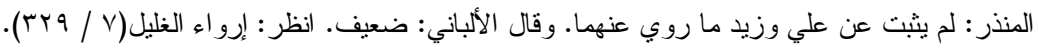


أن في ذلك حكومة. ذهب إليه المالكية (') و الثشافعية(؟).

أدلتهم: - (1) - n

- - لأنه إتلاف جمال من غير منفعة، فلم تجب فيه غير الحكومة.

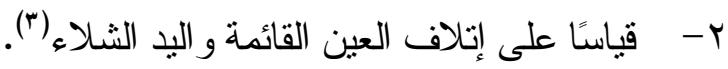

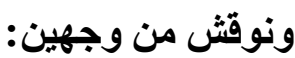

الأول: عدم التسليم بأن ما فيها جمال دون منفعة.

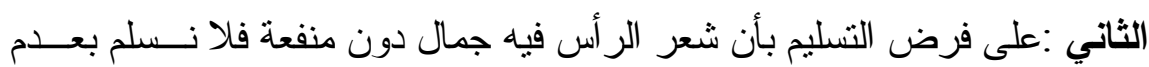

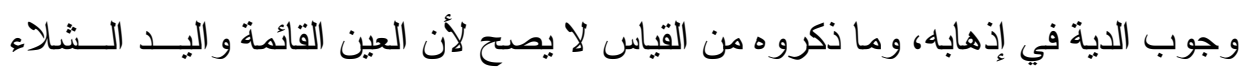
ليس جمالهما كاملًا.

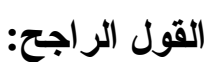

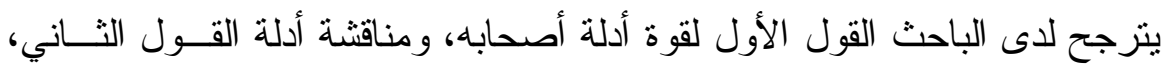

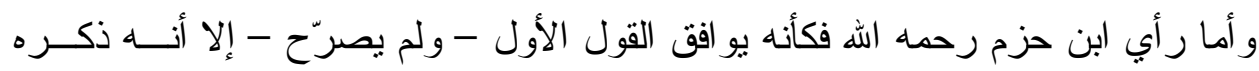
ولم يخالفه، وشنّع على أصحاب القول الثاني. و واله أعلم. 


\section{الخاتمة و النتائج و التوصيات}

الحمد لله الذي بنعمته تتم الصالحات، وترفع الدرجات، و الصلاة والسلام على ولى ولى

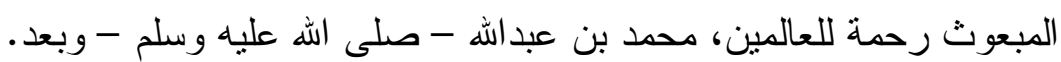

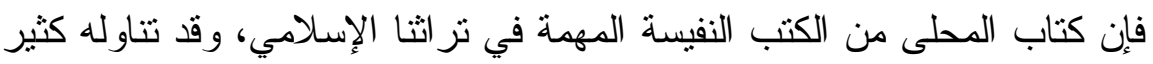

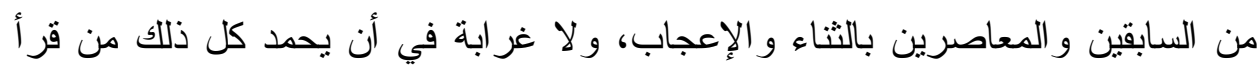

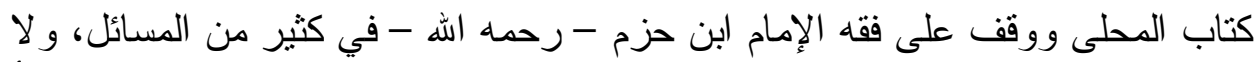
يقدح في مكانته وجود الشذوذ في بعض المسائل - خلافًا لمن عدّ ذلك قادحًا فيه - فكلٌ الاّل يؤخذ من كلامه ويرد إلا مبلغ الرسالة محمدًا صلى الله عليه وسلم. بودئ.

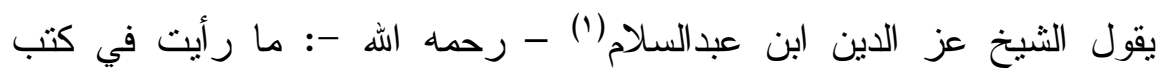
الإسلام في العلم منل " المحلى " لابن حزم، وكتاب " المغني " للشيخ موفق الدين (؟).

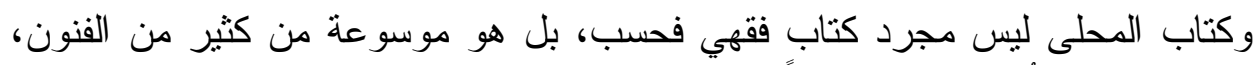

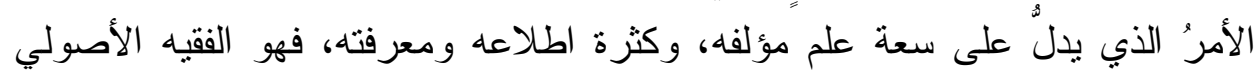
المحدث اللغوي. وتبرز' أهمية هذا الكتاب وتتأكد بما حفظه لنا من آثار الصحابة - رضي الله

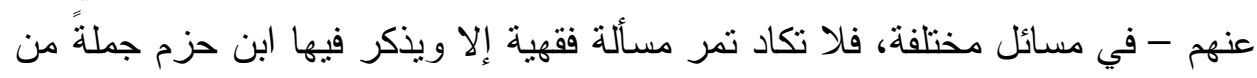
آثار الصحابة - رضي الله عنهم - وينصنُ في كثيرٍ منها على أن ذلك القول لصحابي أو أكثر و لا يعرف له مخالف منهم. وهذه خاتمة المطاف، ونهاية الاقتطاف، سجلت فيها ما نوصلت إليه من نتاج هذه الار اسة، ومن ثُّ التوصيات. أولًا: النتائج. 1- إذا قُعت سن صبي قبل أن يثغر لم يجب في الحال شيء، ولكن يُنتظر عودها

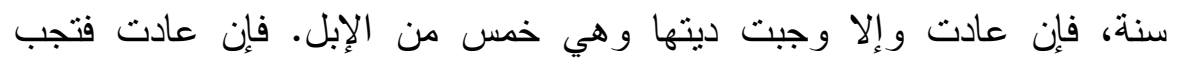
حكومة للألم. ץ- إذا قُلعت السن السوداء الكاملة المنفعة، وجب فيها ثلث ديتها. ( (1) هو عبدالعزيز بن عبدالسلام بن أبي القاسم السُّمي، المشهور بعز الدين بن عبدالسلام، شافعي الدذهب، مسن مؤلفاتسه:

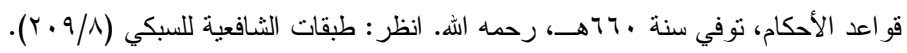

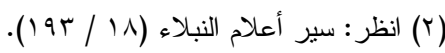


r- إذا فُقئت عين الأعور خطأ وجبت فيها الدية كاملة.

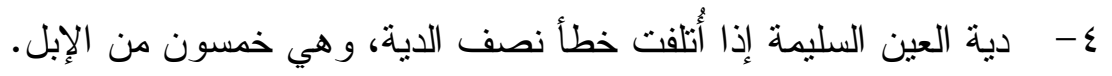

- - في شفر العينين عند إستئصالهما الدية كاملة.

7- تجب الدية كاملة في إبانة الجفون.

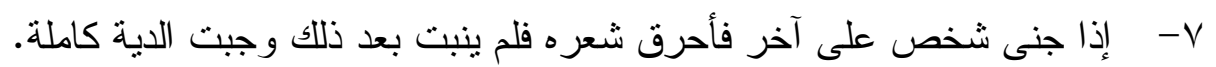

ثانيًا: التوصيات.

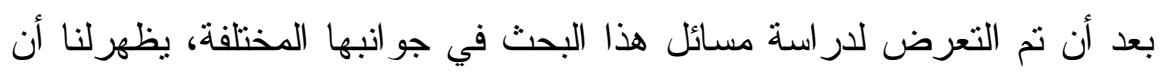

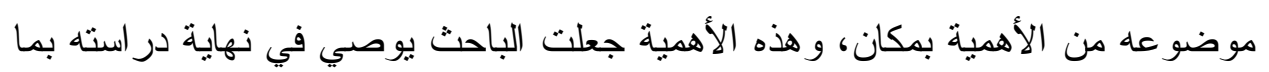
يلي:

1- الحرص على إخر اج هذا المشروع الناجح و الذي تبناه القسم مشكورًا للمكتبات وطلبة العلم، وذلك من خلال موسوعة تتضمن جميع البحوث التي قدمت في هذا المشروع في جميع أبو اب الفقه، فهي بلا شك ستكون إضافة علمية جبارة للمكتبة

$$
\text { الإسلامية. }
$$

r- محاولة استقصاء المسائل المتعلقة بالأبو اب الخاصة بالعبادات التي يذكر فيها ابن

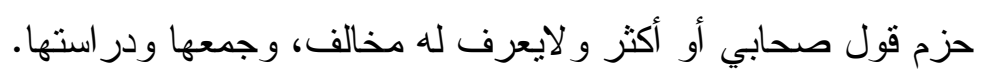

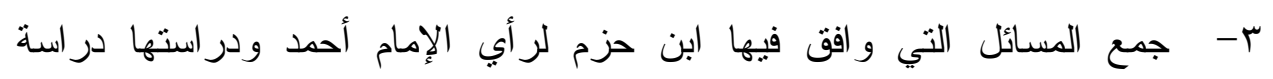
مقارنة.

هذا وأسأل الله تعالى أن يجعل عملي في هذا البحث خالصًا لوجهه الكريم، وأن يوفقني للعلم النافع و العمل الصالح. 


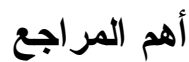

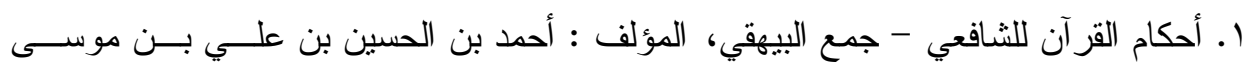

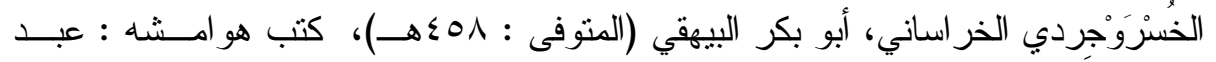

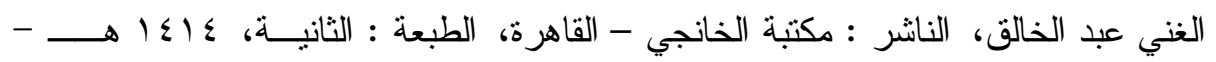
. 1995

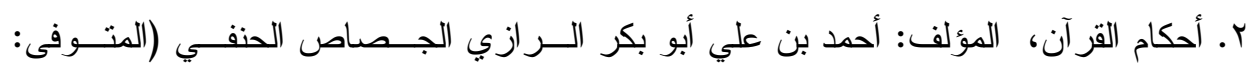

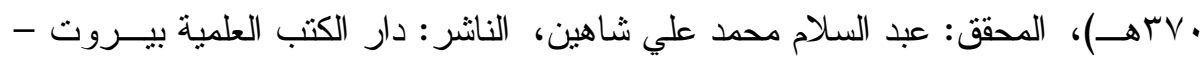

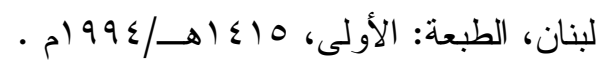

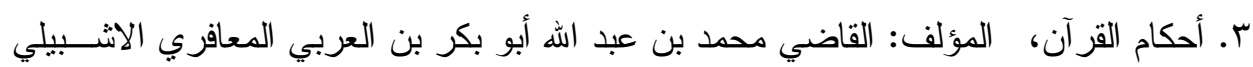

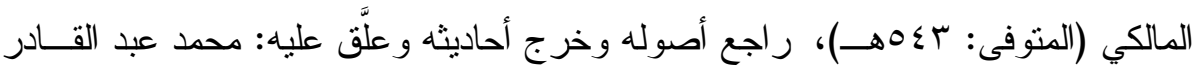

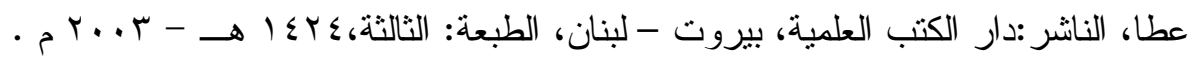

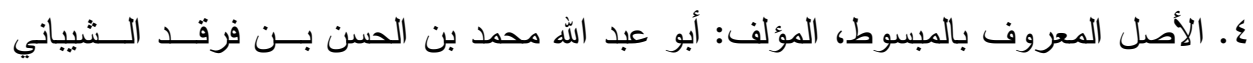

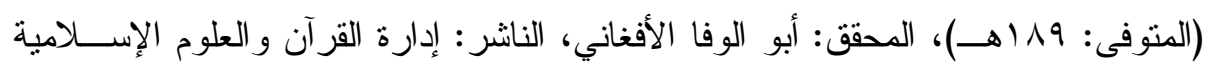

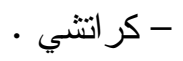

ه. الإقناع في حل ألفاظ أبي شجاع، المؤلف: شمس الدين، محمد بن أحمد الخطيب الـشربيني

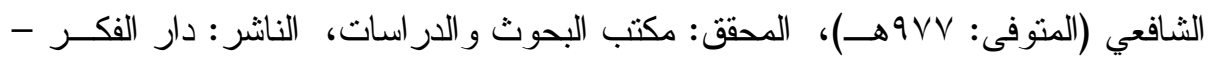
بيروت . 7. الأم، المؤلف: الثافعي أبو عبد الله محمد بن إدريس بن العباس بن عثمان بن شافع بن عبد

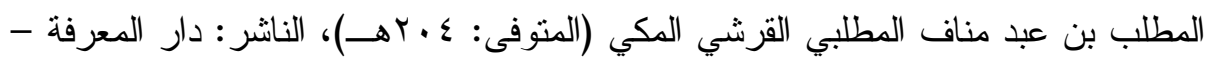

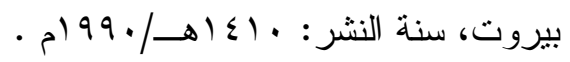

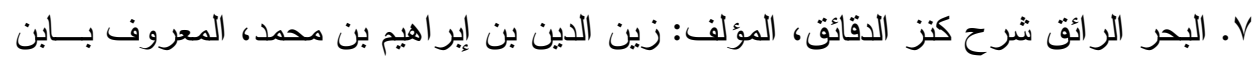

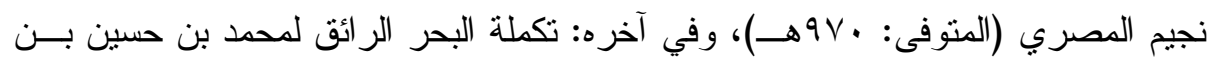

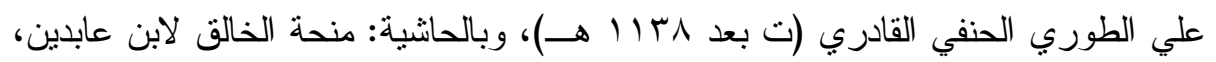
الناشر : دار الكتاب الإسلامي، الطبعة: الثانية .

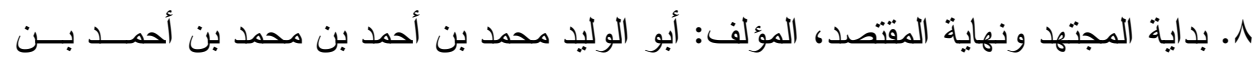

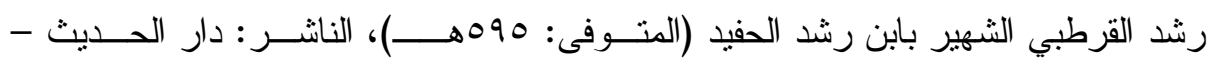

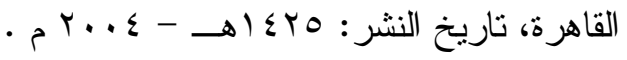




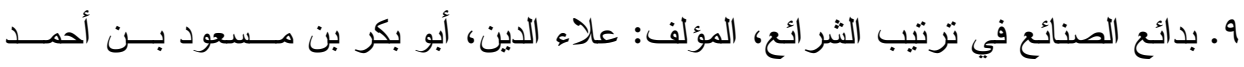

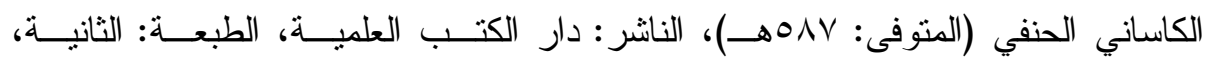

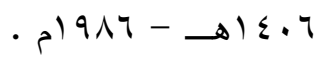

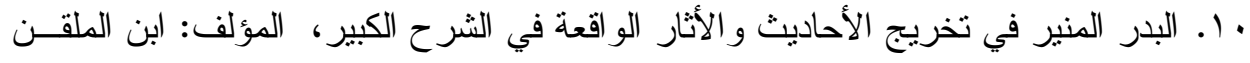

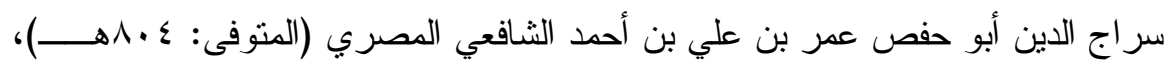

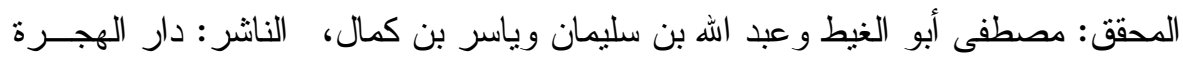

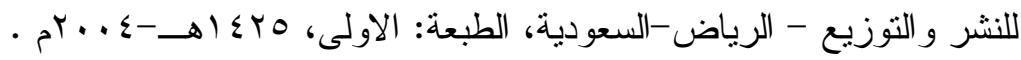

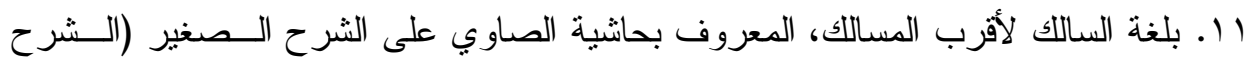

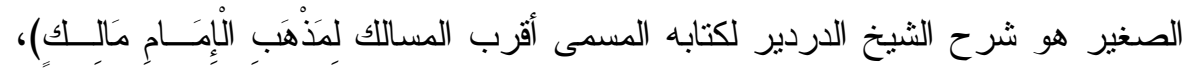

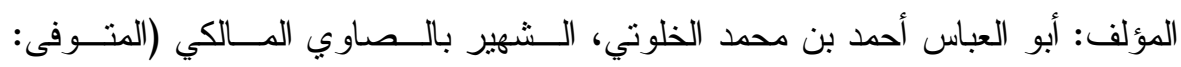

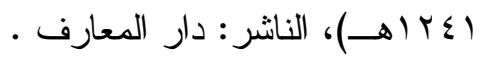

r ا. بيان الوهم و الإيهام في كتاب الأحكام ، المؤلف : علي بن محمد بن عبد الملك الكتــامي

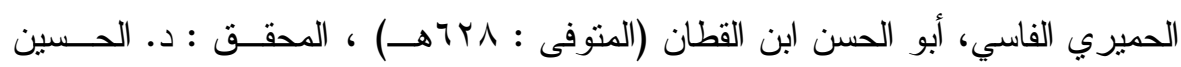

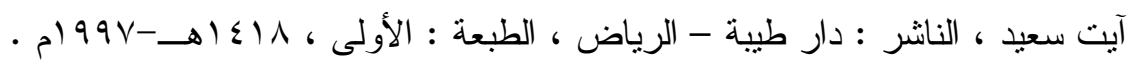

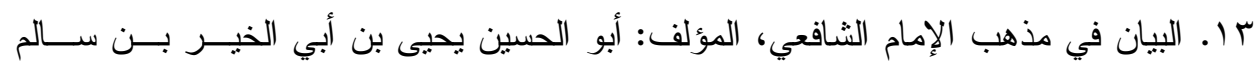

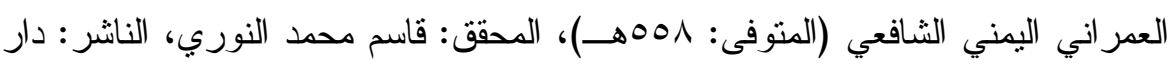

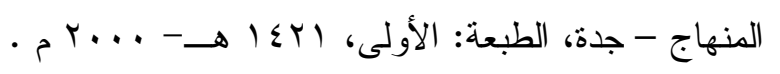

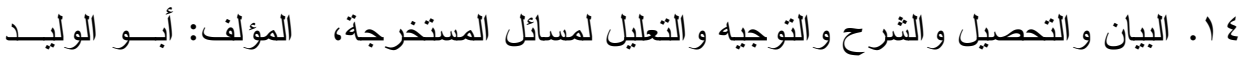

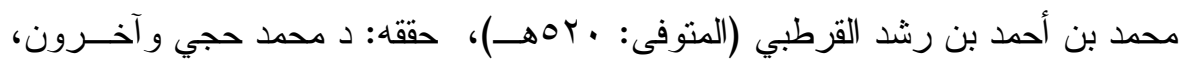

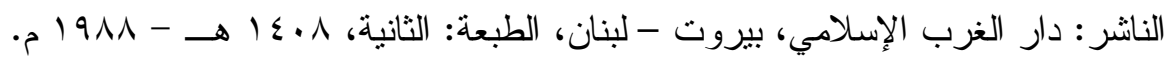

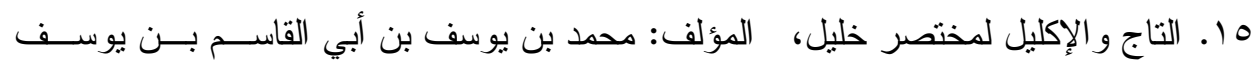

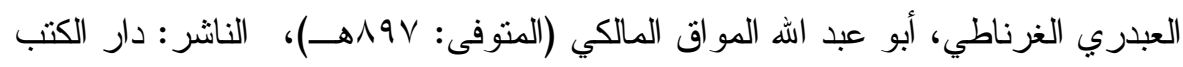

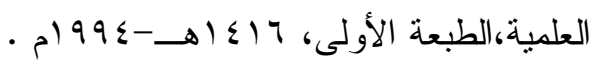

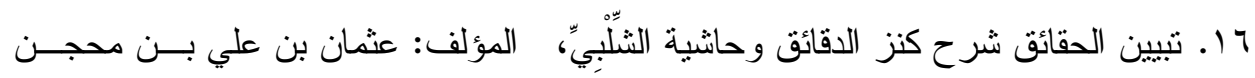

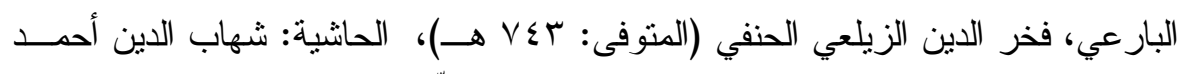

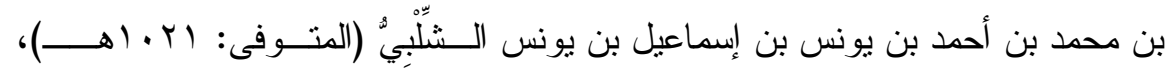

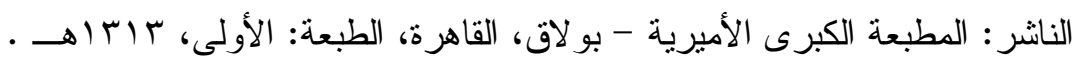


V V. التلخيص الحبير في تخريج أحاديث الر افعي الكبير، المؤلف: أبو الفضل أحمد بن علـي

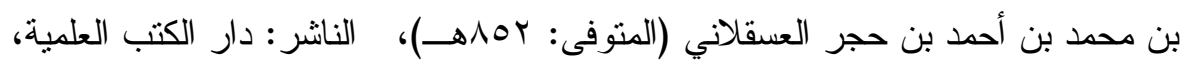

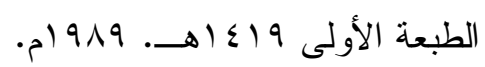

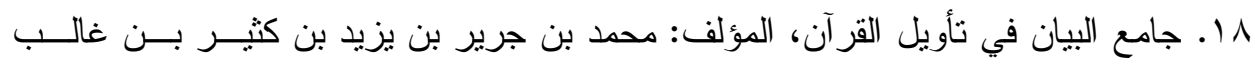

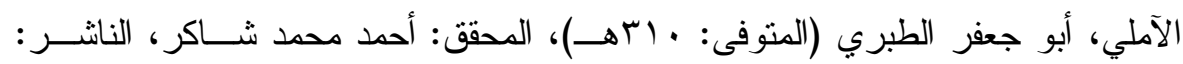

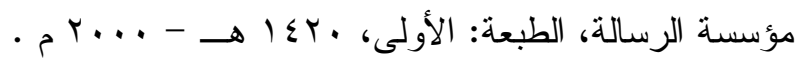

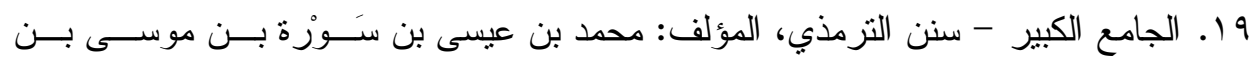

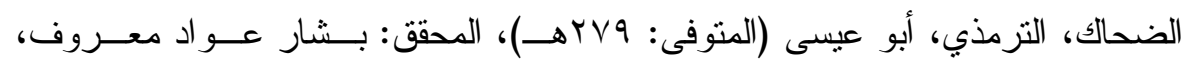

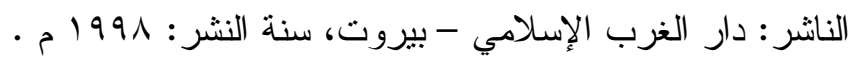

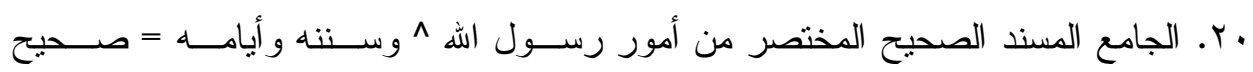
البخاري، المؤلف: محمد بن إسماعيل أبو عبداله البخاري الجعفي، المحقق: محمد زهير

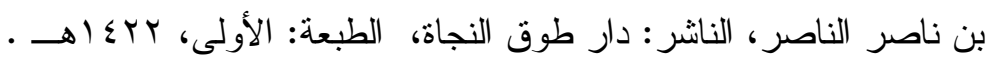

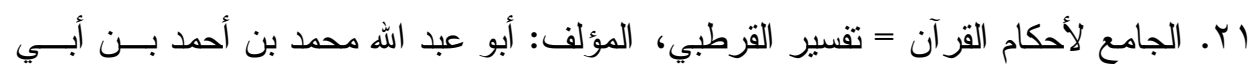

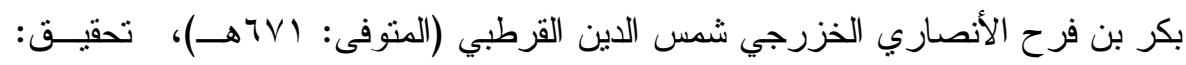
أحمد البردوني وإبر اهيم أطفيش، الناشر : دار الكتب المصرية - القاهرة، الطبعة: الثانية،

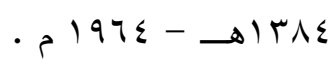
r r. دقائق أولي النهى لثرح المنتهى المعروف بشرح منتهى الإرادات، المؤلف: منصور بن

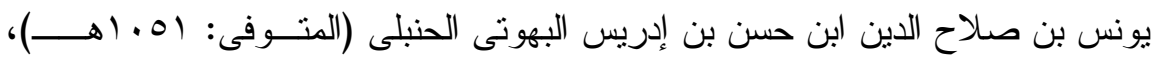

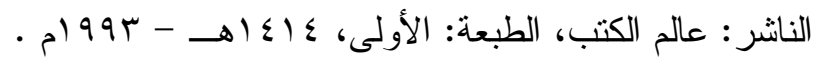

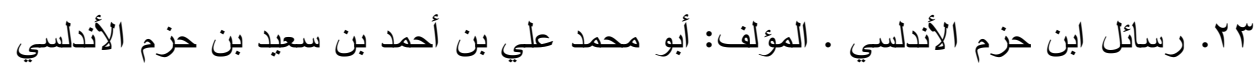

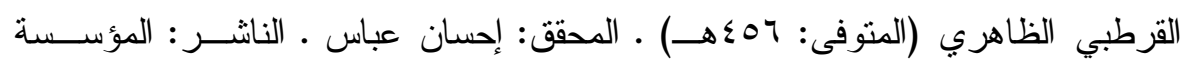

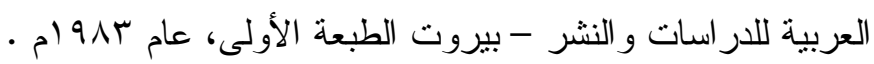

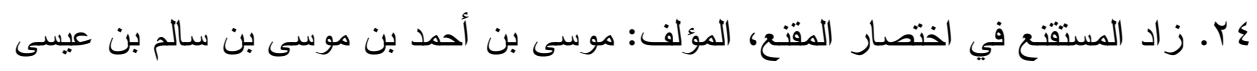

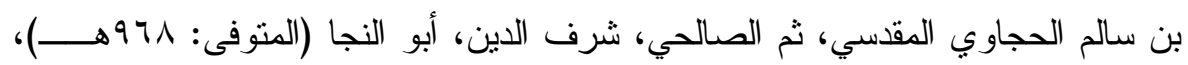

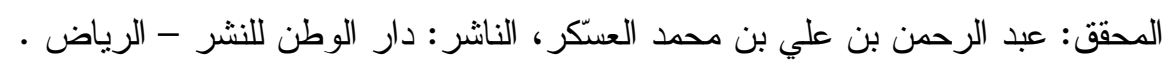


هr. سنن ابن ماجه، المؤلف: ابن ماجة أبو عبد الله محمد بن بزيد القزويني، وماجة اسم أبيه

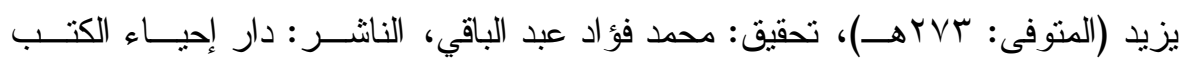

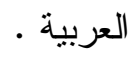

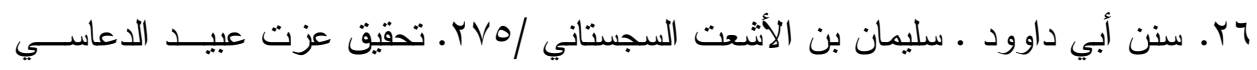

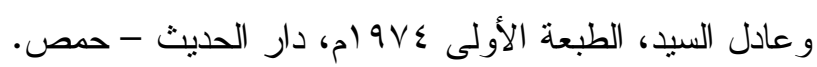

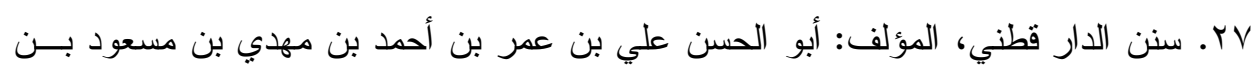

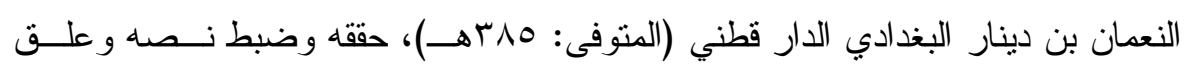

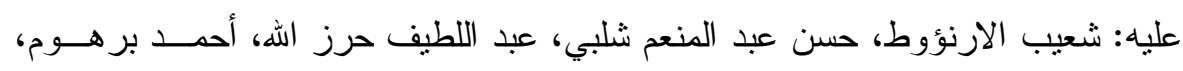

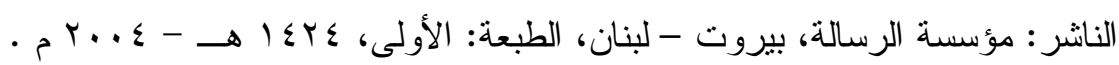

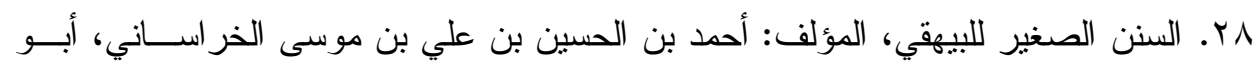

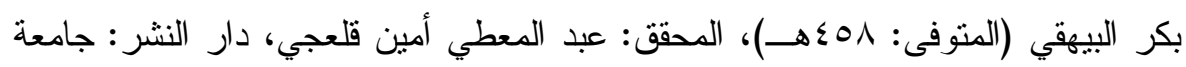

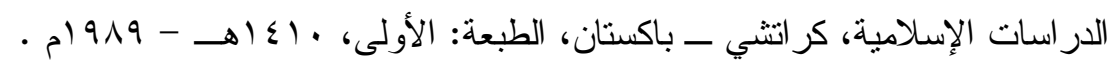

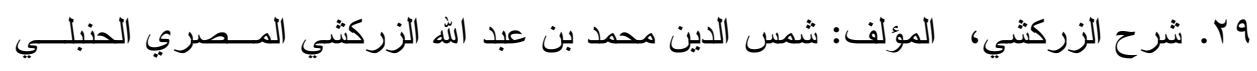

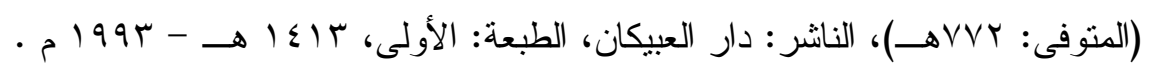

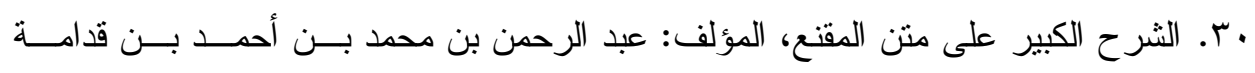

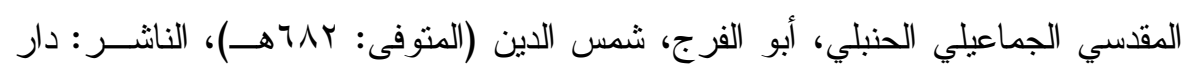

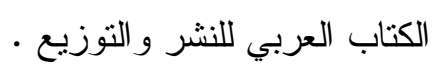

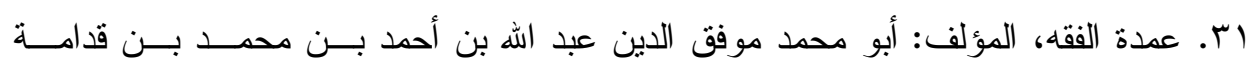

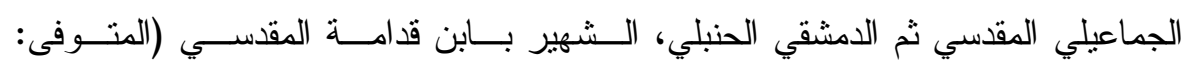

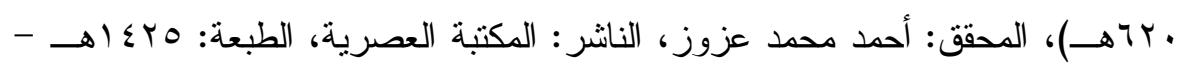

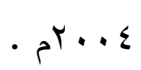

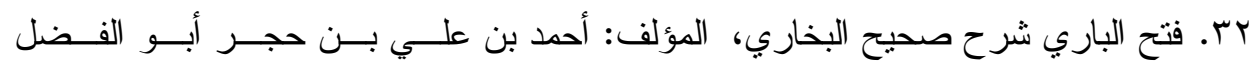

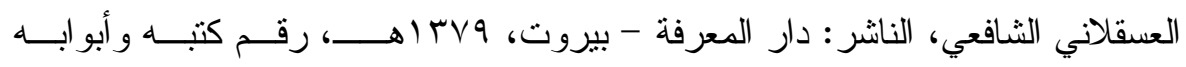

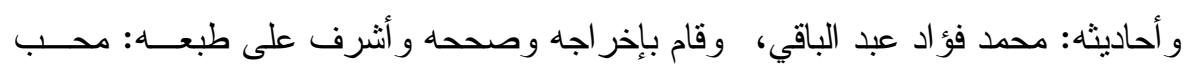

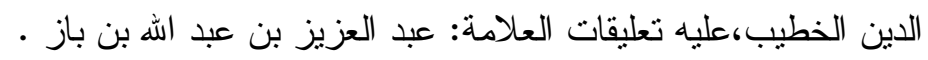


بr. الكافي في فقه الإمام أحمد، المؤلف: أبو محمد موفق الدين عبد الله بن أحمد بن محمد بن

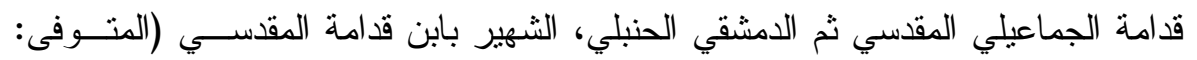

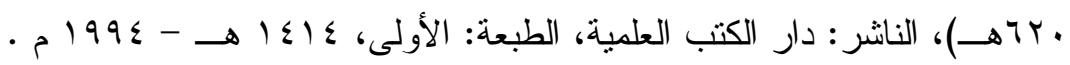
ع r. المجموع شر ح المهذب (مع تكملة السبكي و المطيعي)، المؤلف: أبو زكريا محيب الــدين

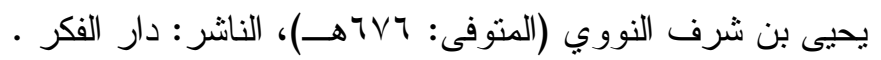

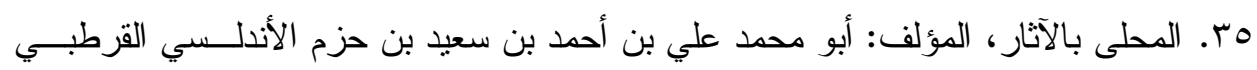

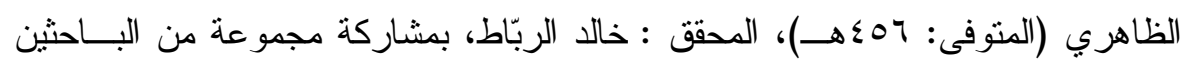

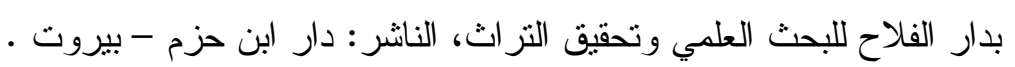

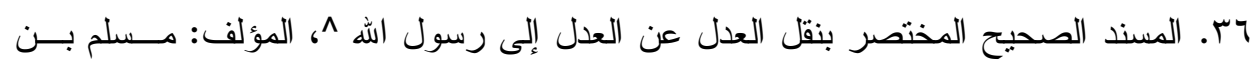

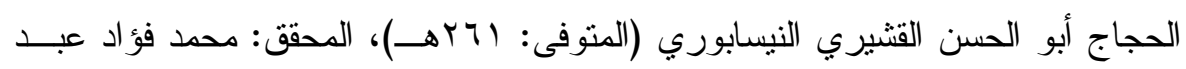

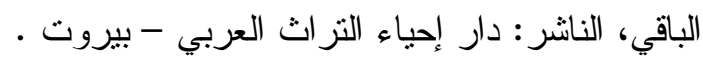
rV

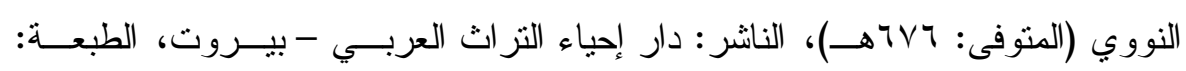

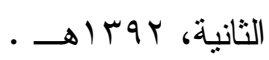


